\title{
Kamu ve Özel Sektörde İş Motivasyonu Uygulaması: Çok Boyutlu Bir Analiz (Work Motivation Practice in Public and Private Sector: A Multidimensional Analysis)
}

\author{
Aykut GÖKSEL iD a Batuhan AYAN iD b \\ a Ankara Hacı Bayram Veli Üniversitesi, İktisadi ve İdari Bilimler Fakültesi, İşletme Bölümü, Ankara, Türkiye. aykut.goksel@hbv.edu.tr \\ b Ankara Hacı Bayram Veli Üniversitesi, Lisansüstü Eğitim Enstitüsü, Yönetim Organizasyon Anabilim Dalı, Ankara, Türkiye. \\ batuhan.ayan@hbv.edu.tr
}

\begin{tabular}{ll}
\hline MAKALE BILGİSI & ÖZET \\
\hline Anahtar Kelimeler: & $\begin{array}{l}\text { Amaç - Bu araştırmanın temel amacı, kamu ve özel sektörde faaliyet gösteren işletmelerdeki işgörenlerin } \\
\text { iş motivasyonu kaynağının belirlenmesi ve demografik özellikler ile iş motivasyonu boyutları arasında } \\
\text { anlamlı bir farklılık olup olmadığın incelenmesidir. }\end{array}$ \\
$\begin{array}{l}\text { Motivasyon } \\
\text { İş Motivasyonu }\end{array}$ & Yöno
\end{tabular}

Özerk Motivasyon

Kontrollü Motivasyon

Gönderilme Tarihi 16 Mart 2021

Revizyon Tarihi 3 Temmuz 2021

Kabul Tarihi 10 Temmuz 2021

Makale Kategorisi: Araştırma Makalesi

Yöntem - Araştırmada, nicel araştırma yöntemlerinden anket tekniği kullanılmıştır. Anket olarak ise Gagne vd. tarafından öz belirleme kuramı temel alınarak geliştirilen iş motivasyonu ölçeği kullanılmıştır. Bu ölçek Çivilidağ ve Şekercioğlu tarafından Türkçe'ye uyarlanmıştır. Bu ölçekte demotivasyon, kontrollü motivasyon ve özerk motivasyon olmak üzere üç temel alt boyut yer almaktadır. Araştırma kapsamında farklı organizasyonlarda çalışan farklı meslek gruplarından toplam 354 kişiye ulaşılmıştır. Anket uygulanan bu kişilerden 218'i özel sektörde, 136'sı kamu sektöründe çalışmaktadır.

Bulgular - Yapılan analizlerde cinsiyet ve eğitim durumu ile demotivasyon ve özerk motivasyon alt boyutları arasında; sektör ile demotivasyon, kontrollü motivasyon ve özerk motivasyon alt boyutları arasında ve iş yerindeki konum ile kontrollü motivasyon alt boyutu arasında anlamlı bir farklılık bulunmuştur. Ancak medeni durumu ve toplam çalışma yılı ile iş motivasyonu boyutları arasında anlamlı bir farklılık bulunamamıştır. Kamu sektörü işgörenlerinin demotivasyon ve kontrollü motivasyon düzeyi özel sektör işgörenlerinden daha yüksek iken kamu sektör işgörenlerinin özerk motivasyon düzeyi özel sektör işgörenlerden daha düşük olduğu görülmüştür.

Tartışma - Araştırmaya katılan işgörenlerin cinsiyeti, eğitim durumu, iş yerindeki konumu ve çalışılan sektörün iş motivasyonu üzerine etkisinin olabileceği değerlendirilmektedir. Araştırmada elde edilen bulgular, literatürdeki diğer çalışmalar ile birlikte değerlendirilerek yöneticilere işgören motivasyonu ile ilgili farklı bakış açıları kazandırabilir.

\section{ARTICLE INFO}

\section{ABSTRACT}

\section{Keywords:}

Motivation

Work Motivation

Autonomous Motivation

Controlled Motivation

Received 16 March 2021

Revised 3 July 2021

Accepted 10 July 2021

Article Classification:

Research Article
Purpose - The main purpose of this study is to determine the source of work motivation of employees in public and private sector enterprises and to examine whether there is a significant difference between demographic characteristics and work motivation dimensions.

Design/methodology/approach - Questionnaire technique, one of the quantitative research methods, was used in the research. As a survey, Gagne et al. The work motivation scale, which was developed on the basis of self-determination theory, was used. This scale was adapted to Turkish by Çivilidağ and Şekercioğlu. In this scale, there are three basic sub-dimensions: demotivation, controlled motivation and autonomous motivation. Within the scope of the research, a total of 354 people from different professional groups working in different organizations were reached. Of these people, 218 work in the private sector, and 136 work in the public sector.

Findings - In the analyzes conducted, a significant relationship was found between gender and educational status, and demotivation and autonomous motivation, between the sector and demotivation, controlled motivation and autonomous motivation and between the position in the workplace and controlled motivation. However, there was no significant relationship between marital status, total working year and job motivation dimensions. While the demotivation and controlled motivation level of the public sector employees is higher than the private sector employees, the autonomous motivation level of the public sector employees is lower than the private sector employees.

Discussion - It is considered that the gender of the employees participating in the study, their education status, their position in the workplace and the sector may have an impact on job motivation. The findings obtained in the research can be evaluated together with other studies in the literature, and can give managers different perspectives on employee motivation. 


\section{GİRİş}

İş görenler, iş hayatının değişmez bir parçasıdır. İster kamu sektöründe isterse özel sektörde olsun örgütsel amaçları gerçekleştirmek için faaliyette bulunan işgörenlerin nitelikleri ve performansları, örgütsel hedeflere ulaşmada önemli ve değerlidir. Örgütsel hedeflere ulaşılması kadar önemli bir diğer konu da örgütsel hedeflere öngörülen zamanda ve belirlenen kriterlere uygun bir şekilde ulaşılmasıdır. Bu noktada iş motivasyonu konusu ön plana çıkmaktadır.

Yönetim biliminde işgören motivasyonu konusu, hem pratik hem de teorik olarak merkezi bir konuma sahiptir. Yöneticiler, organizasyonun tüm düzeylerinde motivasyon konusunu performansın ayrılmaz bir parçası olarak görmektedir. Ancak, örgütsel araştırmacılar motivasyon konusunu yönetim uygulamalarının etkili bir şekilde gerçekleştirilebilmesinde faydalı teorilerin oluşturulabilmesi için temel yapı taşı olarak görmektedir (Steers vd., 2004:379). Oluşturulan motivasyon teorilerinin neredeyse tamam1; cinsiyet (Gökkaya ve Türker, 2018; Akkermans vd., 2016; Ertürk, 2016; Gagne vd., 2014; Ertan ve Kaya, 2012; Yun-Lin, 2012; Yang, 2011; Jehn vd., 2006; Dündar vd., 2007; Eskildsen vd., 2004; Woodard vd., 1998), eğitim düzeyi (Gökkaya ve Türker, 2018; Akkermans vd., 2016; Ertürk, 2016; Gagne vd., 2014; Ertan ve Kaya, 2012; Yun-Lin, 2012; Yang, 2011; Dündar vd., 2007; Jehn vd., 2006; Eskildsen vd., 2004; Woodard vd., 1998), çalışma deneyimi (Akkermans vd., 2016; Ertürk, 2016; Gagne vd., 2014; Ertan ve Kaya, 2012; Yun-Lin, 2012; Yang, 2011; Dündar vd., 2007; Eskildsen vd., 2004; Woodard vd., 1998), meslek ve medeni durum (Gökkaya ve Türker, 2018; Ertan ve Kaya, 2012; Yun-Lin, 2012; Yang, 2011; Dündar vd., 2007; Eskildsen vd., 2004) gibi kişisel faktörlerden bahsetmese de, iş motivasyonunun kişisel faktörlerden etkilendiğine inanılmaktadır (Yang, 2011:276). Kişisel faktörlerden etkilenen iş motivasyonunun örgütsel olarak da önemli etkileri bulunmaktadır. Çünkü, işgörenlerin işyerinde motive edilerek daha yüksek başarı seviyelerine ulaşması ve performansları ile örgüte daha fazla değer katması hedeflenmektedir. Böylece, her bir görev zamanında daha verimli bir şekilde tamamlanabilecek ve işlerin kalitesi de artabilecektir (Ahmed, 2019). Çünkü motive olmayan işgörenlerin performans göstermesi beklenmemelidir (Koçel, 2014:729). Dharma'ya göre (2017) iş motivasyonu ile performans arasında pozitif ve önemli bir etki bulunmaktadır (Dharma, 2017:7). İşgören performansı ile ilgili yöneticilerin karşılaştığı en büyük zorluklardan biri, işgörenlerin her koşulda ellerinden gelenin en iyisini yapmalarını sağlamaktır (Nohria vd., 2008). İnsanlar motive olduklarında en iyi şekilde çalışmaktadırlar, bu durum motivasyonu iş için zorunlu kılmaktadır (Whiteley, 2002). Çünkü örgütler için iş motivasyonun artmasıyla elde edilecek faydalar arasında performans seviyesini iyileştirme, değişime direncin azalması, işgören devir ve devamsızlığının azaltılması, kaynakların verimli kullanımı, artan verimlilik ve çıktı, hedeflere ulaşma, dostluk ilişkilerinin geliştirilmesi, iş gücünde istikrar vb. yer almaktadır (Maniksaly, 2020). Bu faydaların sağlanabilmesi için ise işgörenleri motive eden unsurların ya da işgörenin motivasyon kaynağının yöneticiler tarafından anlaşılması gerekmektedir. Dolayısıyla, motivaston ve iş motivasyonu kavramları ile motivasyon konusuna ilişkin teorik yaklaşımlardan biri olan öz belirleme kuramı araştırma kapsamında incelenmiş ve Gagne vd. tarafından öz belirleme kuramı temel alınarak geliştirilen iş motivasyonu ölçeği kullanılmıştır.

\subsection{Motivasyon Kavramı}

Etimolojik olarak motivasyon, hareket etmek anlamına gelen Latince "movere (to move)" kelimesinden türetilmiştir ve temel olarak harekete geçiren anlamında kullanılmaktadır (Al-Araimi, 2002:208). "Motive" terimi Türkçede ise "güdü, saik veya harekete geçirici“" olarak ifade edilmektedir (Eren, 2019:532).

Atkinson (1964), motivasyonu "yön, canlılık ve eylemin sürekliliği üzerindeki çağdaş (acil) etki” olarak tanımlarken, Vroom (1964) bunu "alternatif gönüllü faaliyet biçimleri arasında kişiler tarafından yapılan seçimi yöneten bir süreç" olarak tanımlamaktadır (Steers vd., 2004:379) . Luthans (1992)'a göre, "bir amaca yönelik davranış ya da güdüyü başlatan, fizyolojik veya psikolojik bir eksiklik veya ihtiyaç" olarak tanımlanan motivayon kavramı Lussier (1996)'e göre ise; “kişiyi ihtiyaçlarını karşılamak üzere davranışa yönlendiren içsel süreç" olarak tanımlanmaktadır (Semerci, 2005:5).

Motivasyon, Robbins (1996:212) tarafından “Bazı bireysel ihtiyaçları karşılama çabasıyla koşullandırılmış, örgütsel hedeflere yüksek düzeyde çaba gösterme isteği" olarak tanımlanmıştır. Pintrich ve Schunk (1996) motivasyonu, bireyler hedefe yönelik eylemleri teşvik ettiğinde ve sürdürdüğünde ortaya çıan süreçler olarak tanımlarken (Yun-Lin, 2012:60) Bartol ve Martin (1998) motivasyonu “davranışa enerji veren, davranışa yön veren ve devam etme eğiliminin altında yatan bir güç" olarak tanımlarlar. Ertürk'e göre motivasyon ise, "bir insan belirlenmiş bir hedef için harekete geçiren güçtür" (Ertürk, 2000:143). Motivasyon, "bir kişinin bir 
görevi gerçekleştirmesinde duygusal veya düşünsel olarak uyarılması ve enerjili bir duruma getirilmesidir" (Şantaş vd., 2018: 66).

Koçel'e (2014) göre motivasyon; "bireylerin belli bir amacı gerçekleştirmek üzere kendi arzu ve istekleri ile davranmaları ve çaba göstermeleridir" (Koçel, 2014:730). Eren'e (2019) göre motivasyon ise "bir veya birden çok insanı, belirli bir yöne (gaye veya amaca) doğru devamlı şekilde harekete geçirmek için yapılan çabaların toplamıdır" (Eren, 2019:532). Gökkaya ve Türker'e göre ise motivasyon, "davranışı açıklamaya yarayan psikolojik süreçlerden biri olan, aynı zamanda kişilerin beklenti ve ihtiyaçları, amaçları, davranışları kendi performansları hakkında bilgi verilmesi konuların içeren bunların yanı sıra istek, amaç, eğilim, davranış, çıkar, seçme, tercih, irade, beklenti, arzu, tatmin, moral gibi kavramları da çağrıştıran bir kavram" dır (Gökkaya ve Türker, 2018:13). Sökmen'e göre yönetsel bağlamda motivasyon, "çalışanın hedefleri çerçevesinde yerine getirmesi gerekenlere yönelimine ilişkindir" (Sökmen vd., 2013:46).

Kleinginna ve Kleinginna'ın 1981 yılında yaptığı bir çalışmada, o zamana kadar ki 98 motivasyon tanımını bir araya getirmiş ve kısaca motivasyonun, insanı harekete geçirmeye yarayan enerji verici / uyandırıcı mekanizmaları ifade ettiği belirtmiştir. $\mathrm{Bu}$ mekanizmalar bazen duyusal girdiyi ve analizi de etkileyebilmektedir (Kleinginna ve Kleinginna, 1981:272).

Burada yer alan ve almayan diğer tanımların buluştuğu ortak payda; motivasyonun insan davranışlarını başlatan, yönlendiren ve sürdüren faktörlerin toplamı olmasıdır (Steers vd., 2004:379). Bir diğer önemli nokta ise motivasyonun bireysel bir olay olması ve ancak bireyin davranışlarında gözlemlenebilmesidir (Koçel, 2010:731).

İşgörenlerin hayatının belirli bir kısmı iş yerlerinde geçmektedir. İşgörenin, hem günlük hayatındaki motivasyonu hem de iş yerindeki motivasyonu gerek işletmeler gerekse işgörenler açısından önemlidir. İş yerinde bireyin motivasyonu, başka bir ifade ile işgören motivasyonu, iş motivasyonu kavramı ile açıklanmaktadır.

\section{2. İş Motivasyonu Kavramı}

Taylor, Gilbert ve Gantt tarafından yapılan çalışmalarda ücretin genellikle temel motivasyon kaynağı olduğunu belirtilmektedir ve iş motivasyonuna ilişkin yaklaşımların tarihi bu çalışmalara kadar uzanmaktadır (Parsons ve Broadbridge, 2006:122). İş motivasyonu ilk defa Pinder (1998) tarafından "bir bireyin varlığından ve ötesinden kaynaklanan, işle ilgili davranışı başlatmak ve onun biçimini, yönünü, yoğunluğunu ve süresini belirlemek için ortaya çıkan bir dizi enerjik güç” şeklinde tanımlanmıştır (Hsu, 2013:181). İş motivasyonu, işgörenlerin iş bağlamında etkin ve verimli bir şekilde çalışmaları için gereken öz motivasyon derecesi olarak da tanımlanabilir (Yun-Lin, 2012:60).

Deci (1972) iş motivasyonun "bir kişinin, belirgin bir ödül olmamasına rağmen bir aktivite gerçekleştirmesi durumunda" ortaya çıktığını savunmaktadır. Kişi aktiviteye girmeyi sevmektedir, çünkü gerçekleştirdiği aktiviteden dolayı iyi hissetmektedir (Akkermans vd., 2016:422). Başka bir ifade ile iş motivasyonu isteğe bağlıdır (Woodard vd., 1998:306).

Woodard vd., (1998) ne göre iş motivasyonu tanımlarının üç ortak unsuru bulunmaktadır. Bunlar (Woodard vd., 1998:306);

- İnsan davranışına enerji veren nedir?

- Davranışı yönlendiren nedir?

- Zaman içinde bu davranışı sürdüren nedir?

Özetle, Nahavandi ve Malekzadeh (1999) motivasyon kavramını örgütsel performansla ilgili yönetim konusu ile ilişkilendirerek motivasyonu; harekete dönüșen zihin, arzu, enerji veya ilgi durumu olarak tanımlamıștır (Al-Araimi, 2002:209). Başka bir ifade ile iş motivasyonu, örgüt amaçlarına ulaşmak için gösterilen yüksek çaba ve isteklilik durumu olarak tanımlanmaktadır (Çayırağası, 2013:37). Motivasyonun, içsel ve dişsal olmak üzere iki kaynağı bulunmaktadır. İçsel motivasyon faktörleri, özellikle bir görev yapma isteğinden, dışsal motivasyon faktörleri ise birey çalışırken görevle ilişkisiz olarak dışarıdan bireyi etkiler (Gökkaya vd., 2018:504). İş motivasyonu ise işgörenlerin iş bağlamında etkin ve verimli bir şekilde çalışmaları için gereken öz motivasyon derecesi olarak tanımlanabilir (Yun-Lin, 2012:60). İş motivasyonunu değerlendirmede kullanılan teorik yaklaşımlardan biri de öz belirleme kuramıdır. 


\section{3. Öz Belirleme Kuramı}

Öz belirleme kuramı (Self Determination Theory), fikirlerini ilk kez 1985 tarihli "Self-Determination and Intrinsic Motivation in Human Behavior" adlı kitaplarında ortaya koyan psikolog Edward Deci ve Richard Ryan'ın çalışmalarından doğmuştur. Öz belirleme kuramı, bireylerin motivasyon kalitesinin, bireylerin davranışlara ne ölçüde dahil olacaklarını ve bunlarla nasıl devam edeceklerini etkilediğini göstermektedir (Hagger vd., 2014:566). Bu kuram, bilişsel bir değerlendirme teorisidir ve bu teorinin temelinde, dişsal motivasyon araçlarının içsel motivasyon üzerindeki etkileri ile ilişkili laboratuvar deneyleri bulunmaktadır. (Ankli ve Palliam, 2012:9). Motivasyondaki diğer teorik yaklaşımların aksine, öz belirleme kuramı dışsal-içsel motivasyon ikilemini kabul etmemektedir; bunun yerine motivasyonu, motive olamamadan içsel motivasyona uzanan bir süreklilik olarak görmektedir (Andrews, 2016:7). Öz belirleme kuramı, kültürler arası geçerliliği olan ve işgörenlerin, geçmişleri ne olursa olsun, gerçek anlamda katılımlarının daha muhtemel olduğunu gösteren bir çerçeve sunmaktadır (Gagne vd., 2014:16).

Öz belirleme kuramı, motivasyon üzerine çok boyutlu bir görüş ileri sürerek bu farklı motivasyon türlerinin nasıl teşvik edileceğini veya vazgeçirileceğini belirtmektedir. Kurama göre motivasyon üç ana kategoride ele alınmaktadır. İlki demotivasyon (amotivation), bir faaliyete yönelik motivasyon eksikliği olarak tanımlanır. İkincisi içsel motivasyon (intrinsic motivation), bireyin kendi iyiliği için, başka bir ifade ile ilgili faaliyetin başlı başına ilginç ve zevkli olmasından dolayı faaliyette bulunmak olarak tanımlanır. Üçüncüsü, dışsal motivasyon (extrinsic motivation) ise, ödül ve onay alma, cezalardan veya eleştirlerden kaçınma, bireyin özsaygısını artırma veya bireysel olarak değer verilen bir hedefe ulaşma gibi araçsal nedenlerle faaliyete dahil olmayı ifade eder (Gagne vd., 2014:2). Bu araçsal nedenler, motivasyonun içselleştirilmesine bağlı olarak değişebilir. İçselleştirme, ödül veya ceza gibi dişsal faktörlerle sağlanan motivasyonun zamanla kabullenilerek içsel düzenleme haline gelmesi anlamına gelmektedir (Gagne vd., 2010:629).

Öz belirleme kuramının merkezindeki kontrollü motivasyon (controlled motivation) ve özerk motivasyon (autonomous motivation) arasında fark vardır (Ankli ve Palliam, 2012:9). Özerk motivasyon bir davranışta bulunmak olarak tanımlanır çünkü davranışın içsel hedefler veya sonuçlarla tutarlı olduğu ve benlikten kaynaklandığı algılanır. Başka bir deyişle, davranış kendi kendini belirler. Özerk nedenlerle hareket eden bireylerin, herhangi bir dış güçlendirme ve beklenmedik durum olmadan bir davranış başlatma ve devam etme olasılığı daha yüksektir. Bu nedenle özerk olarak motive olmuş bireyler, davranışlarının otokontrolünde muhtemelen daha etkilidir. Kontrollü motivasyon ise, özerk motivasyonun aksine, ödül almak veya başkalarından onay almak veya ceza veya suçluluk duygularını önlemek gibi dış kaynaklı nedenlerle davranışlarda bulunmayı yansıtır. Kontrollü motivasyon nedeniyle davranışta bulunan bireyler, davranışa katılırken bir zorunluluk ve baskı hissi duyarlar ve sadece beklenmedik dış durum mevcut olduğu sürece davranışa devam ederler. Eğer davranışı pekiştiren diş etkenler ortadan kalkarsa muhtemelen sergiledikleri davranışlardan vazgeçerler. Bu nedenle kontrolü motive eden bireylerin otokontrollerin daha az olması muhtemeldir. Bu tarz bir davranış, psikolojik ihtiyaçları destekleyici olarak algılanmaz ve bunun yerine ihtiyaç-önlem (need-thwarting) olarak görülebilir (Hagger vd., 2014:566). Özerk motivasyon, bireylerin ideal çalışmasıyla (örneğin refah, performans vb.) olumlu bir şekilde ilişkiliyken, kontrollü motivasyon daha az faydalıdır. Özetle öz belirleme kuramı, motivasyon seviyesinin ve motivasyon türünün değerlendirilmesine izin veren çok boyutlu bir motivasyon kavramsallaştırması sunmaktadır (Gagne vd., 2010:629).

Öz belirleme kuramı temel alınarak Gagné, Forest, Gilbert, Aubé, Morin ve Malorni tarafından 2010 yılında geliştirilen Çok Boyutlu İş Motivasyonu Ölçeği (ÇBİMÖ)'inde dişsal motivasyon dört alt boyuta bölünmüştür. $\mathrm{Bu}$ alt boyutlar; demotivasyon (amotivation), dişsal düzenleme-sosyal (extrinsic regulation social), dişsal düzenleme-maddesel (extrinsic regula-tion material), içe yansitılan düzenleme (introjected regulation), kişisel düzenleme (identified regulation) ve içsel motivasyon (intrinsic motivation) dur. Dişsal düzenelme (external regulation) ve yansitılan düzenleme (introjected regulation) alt boyutları kontrollü motivasyonu (controlled motivation) temsil ederken kişisel düzenleme (identified regulation) ve içsel motivasyon (intrinsic motivation) alt boyutları özerk motivasyon (autonomous motivation) temsil eder. Demotivasyon (amotivation) ise kendisini temsil etmektedir (Deci ve Ryan, 2000:72).

Öz belirleme kuramına göre dışsal motivasyonun alt boyutu olan kişisel düzenleme (hedeflerin, değerlerin ve düzenlemelerin önemi), zamanla içselleşerek içsel motivasyon unsuru haline gelmekte ve içsel motivasyon alt boyutu ile birlikte özerk motivasyonu oluşturmaktadır. Bu yönü ile öz belirleme kuramı temel alınarak 
geliştirilen iş motivasyonu ölçeği diğer motivasyon ölçeklerinden ayrılmaktadır. İş motivasyonuna olan farklı yaklaşımı nedeni ile ilgili ölçek kullanılmıştır. Yerli literatürde bu ölçek kullanılarak yapılan çalışmaların kısıtlı olması ve kamu-özel sektör üzerine yapılmış bir çalışma bulunamaması nedenleri ile araştırma yapılmıştır.

İş motivasyonu birden fazla kaynağa ve bir dizi bireysel, örgütsel ve kültürel faktöre bağlıdır (Toode, vd., 2011; McDonald ve Spence, 2016; Franco vd., 2002; Korlén vd., 2017). Araştırmada, bazı bireysel faktörler ile sektör farklılığının etkisi değerlendirmeye alınmıştır. Bu nedenle, cinsiyet, medeni durum, toplam çalışma süresi, sektör (kamu-özel), iş yerindeki konum ve öğrenim durumu ile iş motivasyonu alt boyutları (demotivasyon, kontrollü motivasyon ve özerk motivasyon) arasında istatistiki olarak anlamlı bir farklılık olup olmadığı incelenmiştir. Bu doğrultuda araştırma hipotezleri şu şekilde oluşturulmuştur.

$\mathrm{H}_{1}$ : Cinsiyet ile iş motivasyonu boyutları arasında anlamlı bir farklılık vardır.

$\mathbf{H}_{2}$ : Medeni durum ile iş motivasyonu boyutları arasında anlamlı bir farklılık vardır.

$\mathbf{H}_{3}$ : Sektör ile iş motivasyonu boyutları arasında anlamlı bir farklılık vardır.

$\mathbf{H}_{4}$ : Çalışma yılı ile iş motivasyonu boyutları arasında anlamlı bir farklılık vardır.

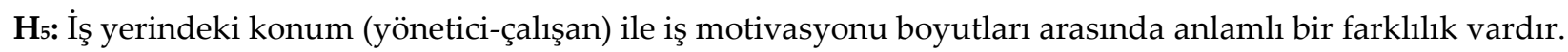

H6: Eğitim durumu ile iş motivasyonu boyutları arasında anlamlı bir farklılık vardır.

Özellikle sektör ve iş yerindeki konum üzerine yapılan incelemeler bu araştırmayı literatürdeki diğer çalışmalardan farklılaştırmaktadır. Bu yönü ile araştırmanın literatüre önemli bir katı sağlaması beklenmektedir.

\section{Yöntem}

\subsection{Amaç}

İşgörenlerin iş hayatlarında etkin ve verimli bir şekilde çalışmaları için gerekli olan öz motivasyon derecesi olarak tanımlanan iş motivasyonun (Yun-Lin, 2012:60) cinsiyet, eğitim düzeyi, çalışma deneyimi, meslek ve medeni durum gibi kişisel faktörlerden etkilendiğine inanılmaktadır (Yang, 2011:276). Bu nedenle araştırmanın amacı, kamu ve özel sektörde faaliyet gösteren işletmelerde işgörenlerin sektör, çalışma yıll, cinsiyet, medeni durum, iş yerindeki konumu (yönetici-çalışan) ve öğrenim durumuna göre iş motivasyonu boyutlarında (demotivasyon, kontrollü motivasyon ve özerk motivasyon) farklılaşma olup olmadığını ve motivasyon kaynağını incelemektir. Elde edilecek sonuçların bu alanda yapılan çalışmalara katkı sunması ve gerek yöneticilerin gerekse işgörenlerin iş motivasyona ilişkin bakış açılarını zenginleştirmesi de amaçlanmaktadır.

\subsection{Evren ve Örneklem}

Araştırma evrenini Türkiye'de faaliyet gösteren kamu ve özel sektördeki hizmet sektöründe çalışanlar oluşturmaktadır. Araştırmada, kolayda örnekleme yöntemi tercih edilmiştir. Araştırma, temsil yeteneğini elde etmek üzere farklı illerdeki (Ankara, İstanbul, Trabzon, Tokat ve Kayseri ağırlıklı olmak üzere Samsun, Kocaeli, Van, Siirt, Antalya, Aydın, Bolu, Çanakkale ve diğer iller) kamu ve özel sektör işgörenlerine 15.09.2020 ile 15.10.2020 tarihleri arasında çevrimiçi anket formu yolu ile gerçekleştirilmiştir. Bu kapsamda özel sektörde faaliyet gösteren organizasyonlardan 218 işgören ve kamu sektöründe faaliyet gösteren organizasyonlardan 136 işgören olmak üzere toplam 354 işgörene anket uygulanmıştır.

TÜIKK (Türkiye İstatistik Kurumu) Ağustos 2020 işgücü istatistiklerine göre Türkiye'de 24 yaş üstü hizmet sektöründe istihdam edilen yaklaşık 12,5 milyon kişi bulunmaktadır. Ulaşılan örneklem büyüklüğü 0,93 güven aralığı (0,07 hata payı) için gerekli olan 323 kişiyi (Yazıcıoğlu ve Erdoğan, 2004: 50) aştığından dolayı örneklemin evreni temsil ettiği değerlendirilmektedir.

\subsection{Veri Toplama Yöntemi}

Araştırmada, Gagne vd. (2014) tarafından öz belirleme kuramı temel alınarak geliştirilen ve dokuz ülkede (Kanada, Belçika, Fransa, Senegal, Birleşik Krallık, Norveç, İsviçre, Çin ve Endonezya), yedi farklı dilde (İngilizce, Fransızca, Almanca, Çince, Endonezya dili, Norveççe ve Felemenkçe) geçerlemesi yapılan çok boyutlu iş motivasyonu ölçeği kullanılmıştır. Bu ölçek Çivilidağ ve Şekercioğlu tarafından Türkçe'ye 
uyarlanması yapılmıştır (Çivilidağ ve Şekercioğlu, 2017). Araştırmada çevrimiçi anket uygulanmıştır. Veri toplama için kullanılan ankette iki bölüm yer almaktadır. İlk bölümde cinsiyet, medeni durum, sektör, çalışma yıll, iş yerindeki konumu (yönetici-çalışan) ve eğitim durumu bilgilerinin olduğu demografik özellikler vardır. İkinci bölümde ise iş motivasyonu anketi vardır. İş motivasyonu anketinde, 19 ifadeden oluşan 7'lü likert ölçeği (1 - Hiç Uygun Değil (not at all), 2 - Çok Az Uygun (very little), 3 - Az Uygun (a little), 4 - Uygun (moderately), 5 - Oldukça Uygun (strongly), 6 - Çok Uygun (very strongly) ve 7 - Tamamen Uygun (completely)) kullanılmıştır. Bu ankette, demotivasyon/güdülenmeme (1,3,5 inci ifadeler ), kontrollü (controlled) motivasyon $(7,9,11,13,14,15,16,17,18,19$ inci ifadeler) ve özerk (autonomous) motivasyon $(2,4,6,8,10,12$ inci ifadeler) olmak üzere temel üç boyut bulunmaktadır.

\subsection{Veri Analizinde Kullanılan Testler}

Araştırmada gruplar arası farklılıkları ortaya çıkarmak amacıyla; cinsiyet, eğitim durumu, sektör ve iş yerindeki konum analizleri için bağımsız örneklem $t$ testi, çalışma yılı analizi için anova testi ve anketteki ifadelere verilen yanıtların ortalamalarını analiz etmek için frekans testi SPSS 24.0 paket programı kullanılarak yapılmıştır.

\section{BULGULAR}

Araştırmada kullanılan anketin genelinin güvenirlilik katsayısı 0.767 olarak tespit edilmiştir. Alt boyutların güvenirlilik katsayısı ise demotivasyon için 0,766 , kontrollü motivasyon için 0,789 ve özerk motivasyon için 0,777 olarak tespit edilmiştir. Bu değerler anketin yeterli seviyede güvenilir olduğunu göstermektedir.

Araştırma kapsamında ulaşılan işgörenlere ilişkin demografik özellikler aşağıdaki tabloda yer aldığı gibidir.

Tablo 1: Araştırmaya katılan işgörenlerin demografik dağılımları

\begin{tabular}{|c|c|c|c|}
\hline Demografik Özellikler & & $\mathbf{n}$ & $\%$ \\
\hline \multirow{5}{*}{ Toplam Çalışma Süresi (Yil) } & $<5$ & 64 & 18,1 \\
\hline & $5-9$ & 107 & 30,2 \\
\hline & $10-14$ & 71 & 20,1 \\
\hline & $15-20$ & 45 & 12,7 \\
\hline & $>20$ & 67 & 18,9 \\
\hline \multirow{2}{*}{ Cinsiyet } & Erkek & 192 & 54,2 \\
\hline & Kadın & 162 & 45,8 \\
\hline \multirow{2}{*}{ Medeni Durum } & Bekar & 110 & 31,1 \\
\hline & Evli & 244 & 68,9 \\
\hline \multirow{2}{*}{ Sektör } & Kamu & 136 & 38,4 \\
\hline & Özel & 218 & 61,6 \\
\hline \multirow{2}{*}{ İş Yerindeki Konum } & Çalışan & 267 & 75,4 \\
\hline & Yönetici & 87 & 24,6 \\
\hline \multirow{4}{*}{ Öğrenim Durumu } & İlkokul - Ortaokul - Lise & 36 & 10,2 \\
\hline & Önlisans & 29 & 8,2 \\
\hline & Lisans & 201 & 56,8 \\
\hline & Lisansüstü & 88 & 24,9 \\
\hline
\end{tabular}

Tablo 1'deki verilere göre araştırmaya katılan işgörenlerin \%18,1'i 5 yıldan az çalışmaktadır, \% 30,2'si 6 - 9 yıl arası çalışmaktadır, \%20,1'i 10 - 14 yıl arası çalışmaktadır, \%12,7'si 15 - 20 yıl arası çalışmaktadır, \%54,2'si erkektir, \%45,8'i kadındır, \%31,1'i bekardır, \%68,9'u evlidir, \%38,4'ü kamu sektöründe çalışmaktadır, 
\%61,16'sı özel sektörde çalışmaktadır, \%75,4'ü çalışandır, \%24,6'ü yöneticidir, \%10,2 ilkokul - ortaokul - lise mezunudur, \%8,2'si önlisans mezunudur, \%56,8'i lisans mezunudur ve $\% 24,9^{\prime}$ u lisansüstü mezunudur.

Demografik özelliklerin dağılımlarına bakıldığında toplam çalışma yılına ve cinsiyete göre dağılımların dengeli olarak gerçekleştiği ifade edilebilir. Diğer demografik özelliklerin dağılımlarının ise istatistiki olarak analiz yapabilmeye engel teşkil etmeyecek şekilde dağıldıkları görülmektedir. Böylece demografik özelliklerin analiz yapmaya uygun ve amaca yönelik bir şekilde dağıldıkları ifade edilebilir.

Araştırmaya katılan işgörenlerin motivasyon düzeyi ile ilgili değerlendirme yapmak amacı ile ankette yer alan ifadelere verilen yanıtlardan en düşük ortalamaya ve en yüksek ortalamaya sahip olan ifadeler incelenmiştir.

Tablo 2: Ölçek ifadelerin ortalama değerleri

\begin{tabular}{|l|c|c|}
\hline & $\begin{array}{c}\text { Ortalama } \\
\text { (n=354) }\end{array}$ & $\begin{array}{c}\text { Standart } \\
\text { Sapma }\end{array}$ \\
\hline 1 - Zamanımı israf ettiğimi düşündüğüm için işimde çaba sarf etmiyorum. & 1,89 & 1,586 \\
\hline 2 - İlginç olduğu için işimde çaba sarf ediyorum. & 4,22 & 2,024 \\
\hline 3 - Çaba sarf etmeye değer olmadığını düşündüğüm için işimde az çaba & 1,79 & 1,463 \\
\hline 4 - Heyecan verici olduğu için işimde çaba sarf ediyorum. & 4,99 & 1,841 \\
\hline 5 - İşim anlamsız olmasına rağmen neden hala bu işi yaptığımı bilmiyorum. & $1,73^{*}$ & 1,478 \\
\hline 6 - İşimi yaparken eğlendiğim için işimde çaba sarf ediyorum. & 5,20 & 1,724 \\
\hline 7 - Başkalarının (amir, meslektaş, aile vb.) onayını almak için işimde çaba sarf & 2,44 & 1,755 \\
\hline 8 - İimde çaba sarf etmenin benim için özel bir anlamı var. & 5,69 & 1,644 \\
\hline 9 - Başkalarının (amir, meslektaş, aile vb.) bana daha fazla saygı duyması için & 3,28 & 2,050 \\
\hline 10 - Bu iş, kişisel değerlerimle uyumlu olduğu için işimde çaba sarf ediyorum. & 5,55 & 1,649 \\
\hline 11 - Başkalarının (amir, meslektaş, aile vb.) bana yönelik eleştirilerinden & 2,74 & 1,924 \\
\hline 12 - Bu işte çaba sarf etmenin kişisel olarak önemli olduğunu düşündüğüm & 5,90 & 1,545 \\
\hline 13 - Ancak işimde yeterince çaba sarf edersem başkaları (işveren, amir vb.) & 2,71 & 2,045 \\
\hline 14 - İşimde çaba sarf ederim aksi halde, kendimi kötü hissederim. & $6,18^{*}$ & 1,305 \\
\hline 15 - İşimde yeterince çaba sarf edersem başkaları (işveren, amir vb.) bana daha & 3,36 & 2,185 \\
\hline 16 - Şimdiki işimde çaba sarf ederim aksi halde, kendimi mahcup hissederim, & 5,81 & 1,539 \\
\hline 17 - İsimde yeterince çaba sarf etmezsem işimi kaybetme riskim olur. & 3,65 & 2,162 \\
\hline 18 - İşim, kendimle gurur duymamı sağladı̆̆ı için işimde çaba sarf ediyorum. & 5,79 & 1,643 \\
\hline 19 - Kendimi kanıtlamak zorunda olduğum için işimde çaba sarf ediyorum. & 3,53 & 2,121 \\
\hline
\end{tabular}

Tablo 2 ‘de yer alan veriler ışığında araştırmaya katılan işgörenlerin en fazla 14. ifade olan "İşimimde çaba sarf ederim aksi halde, kendimi kötü hissederim." ifadesini tercih ettiği ifade edilebilir. En az tercih edilen ifade ise 5. ifade olan "İşim anlamsız olmasına rağmen neden hala bu işi yaptığımı bilmiyorum." ifadesidir. 
A. Göksel - B. Ayan 13/3 (2021) 2174-2187

Tablo 3: İş motivasyon boyutları ile cinsiyet arasındaki ilişkiye ilişkin bağımsız örneklem $t$ testi sonuçları

\begin{tabular}{|l|c|c|c|c|}
\hline İş Motivasyonu Boyutları & Cinsiyet & Ortalama & Standart Sapma & $\mathbf{p}$ \\
\hline \multirow{2}{*}{ Demotivasyon } & Erkek & 1,9394 & 1,21121 & \multirow{2}{*}{, $\mathbf{0 0 0}$} \\
\cline { 2 - 4 } & Kadın & 1,5093 &, 98041 & \\
\hline \multirow{2}{*}{ Kontrollü Motivasyon } & Erkek & 3,9005 & 1,09576 & \multirow{2}{*}{, 785} \\
\cline { 2 - 4 } & Kadın & 3,9323 & 1,07160 & \multirow{2}{*}{, 040} \\
\hline \multirow{2}{*}{ Özerk Motivasyon } & Erkek & 5,1248 & 1,21490 & \\
\cline { 2 - 4 } & Kadın & 5,3982 &, 09233 & \\
\hline
\end{tabular}

Tablo 3 'te yer alan veriler iş motivasyonu boyutları ile cinsiyet arasındaki ilişkiyi analiz etmek için gerçekleştirilen bağımsız örneklem $t$ test sonuçlarıdır. İş motivasyonu boyutlarından kontrollü motivasyon alt boyutunun $\mathrm{p}$ değeri $0,05^{\prime}$ ten büyüktür. Demotivasyon ve özek motivasyon alt boyutlarının $\mathrm{p}$ değeri ise 0,05'ten küçüktür. Bu sonuca göre cinsiyet ile demotivasyon ve özerk motivasyon alt boyutları arasında istatistiki olarak anlamlı bir farklılık bulunmaktadır. Kadın işgörenlerin demotivasyon düzeyi erkek işgörenlerden daha düşüktür. Başka bir ifade ile kadın işgörenler erkek işgörenlerden daha motivedir. Ayrıca kadın işgörenlerin özerk motivasyonu erkek işgörenlerden daha yüksek olduğu ifade edilebilir.

Tablo 4: İş motivasyon boyutları ile medeni durum arasındaki ilişkiye ilişkin bağımsız örneklem $t$ testi sonuçları

\begin{tabular}{|l|c|c|c|c|}
\hline İş Motivasyonu Boyutları & Medeni Durum & Ortalama & Standart Sapma & $\mathbf{p}$ \\
\hline \multirow{2}{*}{ Demotivasyon } & Bekar & 1,6667 & 1,09489 & \multirow{2}{*}{, 408} \\
\cline { 2 - 4 } & Evli & 1,7745 & 1,14575 & \\
\hline \multirow{2}{*}{ Kontrollü Motivasyon } & Bekar & 3,8755 & 1,04760 & \multirow{2}{*}{, 642} \\
\cline { 2 - 4 } & Evli & 3,9336 & 1,10096 & \multirow{2}{*}{, 564} \\
\hline \multirow{2}{*}{ Özerk Motivasyon } & Bekar & 5,1924 & 1,15849 & 1,22116 \\
\cline { 2 - 4 } & Evli & 5,2724 & \\
\hline
\end{tabular}

Tablo 4 'te yer alan veriler iş motivasyonu boyutları ile medeni durum arasındaki ilişkiyi analiz etmek için gerçekleştirilen bağımsız örneklem $t$ test sonuçlarıdır. İş motivasyonu alt boyutların tamamının $p$ değeri 0,05'ten büyüktür. Bu sonuca göre medeni durum ile iş motivasyonu arasında istatistiki olarak anlamlı bir farklılık bulunmamaktadır.

Tablo 5: İş motivasyon boyutları ile sektör arasındaki ilişkiye ilişkin bağımsız örneklem $\mathrm{t}$ testi sonuçları

\begin{tabular}{|c|c|c|c|c|}
\hline İş Motivasyonu Boyutları & Sektör & Ortalama & Standart Sapma & $\mathbf{p}$ \\
\hline \multirow{2}{*}{ Demotivasyon } & Kamu & 1,9669 & 1,28758 & \multirow{2}{*}{,004 } \\
\hline & Özel & 1,6037 & 1,00084 & \\
\hline \multirow{2}{*}{ Kontrollü Motivasyon } & Kamu & 4,1794 & 1,14346 & \multirow{2}{*}{,000 } \\
\hline & Özel & 3,7558 & 1,01497 & \\
\hline \multirow{2}{*}{ Özerk Motivasyon } & Kamu & 5,0458 & 1,23829 & \multirow{2}{*}{ 015 } \\
\hline & Özel & 5,3687 & 1,16337 & \\
\hline
\end{tabular}

Tablo 5 'te yer alan veriler iş motivasyonu boyutları ile sektör arasındaki ilişkiyi analiz etmek için gerçekleştirilen bağımsız örneklem $t$ test sonuçlarıdır. İş motivasyonu boyutlarından demotivasyon, kontrollü motivasyon ve özerk motivasyon alt boyutlarının p değeri 0,05 'ten küçüktür. Bu sonuca göre sektör ile 
demotivasyon, kontrollü motivasyon ve özerk motivasyon arasında istatistiki olarak anlamlı bir farklılık bulunmaktadır. Başka bir ifade ile demotivasyon, özel sektöre göre kamu sektöründe çalışanlarda daha yüksek olduğu ifade edilebilir. Kontrollü motivasyon, kamu sektöründe özel sektöre göre daha yüksek olduğu ifade edilebilir. Özerk motivasyon, özel sektörde kamu sektörüne göre daha yüksek olduğu ifade edilebilir.

Tablo 6: İş motivasyon boyutları ile iş yerindeki konum arasındaki ilişkiye ilişkin bağımsız örneklem t testi sonuçları

\begin{tabular}{|l|c|c|c|c|}
\hline \multirow{2}{*}{ İş Motivasyonu Boyutları } & İş Yerindeki & Ortalama & Standart Sapma & $\mathbf{p}$ \\
\hline \multirow{2}{*}{ Kemotivasyon } & Çalışan & 1,6971 & 1,07910 & \multirow{2}{*}{208} \\
\cline { 2 - 4 } & Yönetici & 1,8745 & 1,27031 & \multirow{2}{*}{, $\mathbf{0 2 4}$} \\
\hline \multirow{2}{*}{ Özerk Motivasyon } & Çalışan & 3,8411 & 1,05490 & \multirow{2}{*}{, 468} \\
\cline { 2 - 4 } & Yönetici & 4,1447 & 1,14263 & 1,23051 \\
\cline { 2 - 4 } & Çalışan & 5,2205 & 1,10583 & \\
\cline { 2 - 4 } & Yönetici & 5,3294 & \\
\hline
\end{tabular}

Tablo 6 'da yer alan veriler iş motivasyonu boyutları ile iş yerindeki konum arasındaki ilişkiyi analiz etmek için gerçekleştirilen bağımsız örneklem $t$ test sonuçlarıdır. İş motivasyonu boyutlarından demotivasyon ve özerk motivasyon alt boyutlarının p değeri 0,05'ten büyüktür. Kontrollü motivasyon alt boyutunun p değeri ise 0,05 ten küçüktür. Bu sonuca göre iş yerindeki konum ile kontrollü motivasyon alt boyutu arasında istatistiki olarak anlamlı bir farklılık bulunmaktadır. Başka bir ifade ile yöneticilerin kontrollü motivasyonu çalışanlara göre daha yüksek olduğu ifade edilebilir.

Tablo 5: İş motivasyon boyutları ile toplam çalışma süresi ile arasındaki ilişkiye ilişkin ANOVA testi sonuçları

\begin{tabular}{|l|c|c|}
\hline İş Motivasyonu Boyutları & F & p \\
\hline Demotivasyon &, 358 &, 839 \\
\hline Kontrollü Motivasyon &, 612 &, 654 \\
\hline Özerk Motivasyon & 2004,8 &, 52 \\
\hline
\end{tabular}

Tablo 7 'de yer alan veriler iş motivasyonu boyutları ile toplam çalışma süresi arasındaki ilişkiyi analiz etmek için gerçekleştirilen ANOVA testi sonuçlarıdır. İş motivasyonu boyutlarından demotivasyon, kontrollü motivasyon ve özerk motivasyon alt boyutlarının p değeri $0,05^{\prime}$ ten büyüktür. Buna sonuca göre toplam çalışma süresi ile iş motivasyonu boyutları arasında istatistiki olarak anlamlı bir farklılık bulunmamaktadır.

Tablo 6: İş motivasyon boyutları ile eğitim durumu arasındaki ilişkiye ilişkin ANOVA testi sonuçları

\begin{tabular}{|c|c|c|c|c|}
\hline İş Motivasyonu Boyutları & Eğitim Durumu & Ortalama & $\mathbf{F}$ & $\mathrm{p}$ \\
\hline \multirow{4}{*}{ Demotivasyon } & Lise & 2,1979 & \multirow{4}{*}{3,013} & \multirow{4}{*}{,030 } \\
\hline & Önlisans & 2,0230 & & \\
\hline & Lisans & 1,7248 & & \\
\hline & Lisansüstü & 1,6335 & & \\
\hline \multirow{4}{*}{ Kontrollü Motivasyon } & Lise & 4,1031 & \multirow{4}{*}{,383 } & \multirow{4}{*}{,765 } \\
\hline & Önlisans & 3,8379 & & \\
\hline & Lisans & 3,9045 & & \\
\hline & Lisansüstü & 3,8965 & & \\
\hline \multirow{4}{*}{ Özerk Motivasyon } & Lise & 4,5625 & \multirow{4}{*}{4,908} & \multirow{4}{*}{,002 } \\
\hline & Önlisans & 5,0057 & & \\
\hline & Lisans & 5,3109 & & \\
\hline & Lisansüstü & 5,4341 & & \\
\hline
\end{tabular}




\section{A. Göksel - B. Ayan 13/3 (2021) 2174-2187}

Tablo 8'de yer alan veriler iş motivasyonu boyutları ile öğrenim durumu arasındaki ilişkiyi analiz etmek için gerçekleştirilen ANOVA testi sonuçlarıdır. İş motivasyonu boyutlarından demotivasyon ve özerk motivasyon alt boyutlarının p değeri $0,05^{\prime}$ ten küçüktür. Kontrollü motivasyon alt boyutunun p değeri ise $0,05^{\prime}$ ten büyüktür. Buna sonuca göre eğitim durumu ile kontrollü motivasyon alt boyutu arasında istatistiki olarak anlamlı bir farklılık bulunmaktadır. Ancak işgörenlerin eğitim durumu ile demotivasyon ve özerk motivasyon alt boyutları arasında istatistiki olarak anlamlı bir farklılık bulunmaktadır. Eğitim durumun göre iş motivasyonu boyutlarındaki ortalama değerler değerlendirildiğinde, eğitim düzeyi arttıkça demotivasyon düzeyi azalmakta, özerk motivasyon düzeyi ise artmakta olduğu ifade edilebilir. Başka bir ifade ile eğitim düzeyi arttıkça motivasyon düzeyi de artmakta ve bu motivasyonun kaynağı özerk (içsel) motivasyon olmaktadır.

\section{SONUÇ VE TARTIŞMA}

İşgörenlerin iş hayatlarında etkin ve verimli bir şekilde çalışmaları için gerekli olan öz motivasyon derecesi olarak tanımlanan iş motivasyonun (Yun-Lin, 2012:60) cinsiyet, eğitim düzeyi, çalışma deneyimi, meslek ve medeni durum gibi kişisel faktörlerden etkilendiğine inanılmaktadır (Yang, 2011:276). Bu çalışmada da cinsiyet, medeni durum, toplam çalışma süresi, sektör (kamu-özel), iş yerindeki konum ve öğrenim durumu ile iş motivasyonu arasındaki ilişki incelenmiştir.

İşgörenlerin cinsiyet ile iş motivasyonu boyutları arasındaki farklılaşmanın analizi için bağımsız örneklem $t$ testi uygulanmış ve bu sonuca göre cinsiyet ile demotivasyon ve özerk motivasyon alt boyutları arasında istatistiki olarak anlamlı bir farklılık bulunmaktadır. Başka bir ifade ile kadın işgörenlerin $(X=1,5093)$ demotivasyon düzeyi erkek işgörenlerden $(X=1,9394)$ daha düşüktür. Kadın işgörenlerin $(X=5,3982)$ özerk motivasyon düzeyi erkek işgörenlerden $(X=5,1248)$ daha yüksektir. Bu durumda $\mathrm{H}_{1}$ hipotezi (Cinsiyet ile iş motivasyonu boyutları arasında anlamlı bir farklılık vardır.) demotivasyon ve özerk motivasyon alt boyutları için kabul edilmiştir. Elde edilen sonuçlar Ertürk (2016) ve Eskildsen vd. (2004) çalışmalarında elde edilen sonuçlar ile benzerlik göstermektedir. Ancak Dündar vd. (2007), Ertan ve Kaya (2012) ve Jehn vd. (2006) çalışmalarında elde edilen sonuçlar ile benzerlik göstermemektedir. Literatürdeki farklı sonuçlar cinsiyet ile iş motivasyonu boyutları arasında kesin bir ilişkiden söz edilemeyeceğini ifade edebilir. Sonuçların farklılık göstermesinin nedenleri arasında çalışılan sektör (kamu ve özel sektörden ziyade enerji, finans, gida vb. sektörler ), çalışma ortamı, işgörenin sevdiği işi yapıp yapmaması, iş yerindeki çatışmalar, bireyin kişilik özellikleri gibi unsurlar sıralanabilir. Ayrıca kadın işgörenlerin iş hayatında yaşadığı zorluklar özerk (içsel) motivasyonlarının artmasına da neden olmuş olabilir.

İşgörenlerin eğitim durumu ile iş motivasyonu boyutları arasındaki farklılaşmanın analizi için tek yönlü anova testi uygulanmış ve bu sonuca göre eğitim durumu ile demotivasyon ve özerk motivasyon alt boyutları arasında istatistiki olarak anlamlı bir farklılık bulunmaktadır. Başka bir ifade ile eğitim düzeyi arttıkça demotivasyon düzeyi azalmakta, özerk motivasyon düzeyi ise artmaktadır. Bu durumda $\mathrm{H}_{6}$ hipotezi (Eğitim durumu ile iş motivasyonu boyutları arasında anlamlı bir farklılık vardır.) demotivasyon ve özerk motivasyon alt boyutları için kabul edilmiştir. Elde edilen bu sonuçlar Dündar vd. (2007), Ertan ve Kaya (2012) ve Ertürk (2016) ile benzerlik göstermektedir. Ancak Eskildsen vd. (2004) ve Jehn vd. (2006) çalışmalarında elde edilen sonuçlar ile benzerlik göstermemektedir. Çalışmalarda farklılık gösteren ilişkilerin temel nedeni iki şekilde ifade edilebilir. Birincisi, birey dışsal bir neden dolayı eğitim seviyesini yükseltmek zorunda kalmış olabilir. İkincisi ise, birey kendini alanında geliştirmek, daha bilgili bir hale gelebilmek, işini daha profesyonel bir şekilde yapabilmek ya da ilgi duyduğu bir alanda bilgi sahibi olabilmek gibi içsel nedenlerden dolayı eğitim seviyesini yükseltmeyi tercih etmiş olabilir. Her iki durum, literatürdeki farklı sonuçları açıklamaya yardımcı olabileceği değerlendirilmektedir.

İşgörenlerin sektör (kamu - özel) ile iş motivasyonu boyutları arasındaki farklılaşmanın analizi için bağımsız örneklem $\mathrm{t}$ testi uygulanmış ve bu sonuca göre sektör ile demotivasyon, kontrollü motivasyon ve özerk motivasyon alt boyutları arasında istatistiki olarak anlamlı bir farklılık bulunmaktadır. Başka bir ifade ile kamu işgörenlerinin $(X=1,9669)$ demotivasyon düzeyi özel işgörenlerden $(X=1,6037)$ daha yüksektir. Kamu işgörenlerinin $(X=4,1794)$ kontrollü motivasyon düzeyi özel işgörenlerden $(X=3,7558)$ daha yüksektir. Kamu işgörenlerinin $(X=5,0458)$ özerk motivasyon düzeyi özel işgörenlerden $(X=5,3687)$ daha düşüktür. Bu durumda $\mathrm{H}_{3}$ hipotezi (Sektör ile iş motivasyonu boyutları arasında istatistik olarak anlamlı bir farklılık vardır.) kabul edilmiştir. Literatürde, konu ile ilgili bir incelemeye rastlanılamamıştır. Kamu ve özel sektörde 
motivasyon konusunu etkileyebilecek önemli farklılıklar bulunmaktadır. Kamu da gerçekleştirilen her faaliyetin kanun ve yönetmeliklerle düzenlenmesi nedeni ile kullanılabilecek motivasyon unsurları özel sektöre göre çok sınırlı kalmaktadır. Ayrıca kamu da uygulanan bürokratik yapıdan kaynaklı olarak işgörenlerin her faaliyetinden yöneticisi de sorumlu olduğu için işgörenlerin kendi yetki alanındaki bazı kararları alırken bile yöneticisinin onayını alması gerekmektedir. Başka bir ifade ile kamuda yetki devri ve personel güçlendirme uygulamaları sınırlı kalmaktadır. Ayrıca bazı kamu kurumlarındaki faaliyetler dışında genel olarak kamu da yürütülen faaliyetler rutin faaliyet olarak nitelendirilebilir. Tüm bu nedenlerden dolayı araştırmada elde edilen sonuca göre kamu sektöründe çalışanlarının özel sektörde çalışanlara göre daha düşük motivasyona ve daha yüksek kontrollü motivasyona sahip olmasını açıklayabilir. Özel sektörde içsel motivasyon unsurlarının uygulanabilirliğinin daha fazla olması nedeni ile de özel sektörde çalışanların özerk motivasyon düzeylerinin kamu sektöründe çalışanlara göre daha yüksek olduğu sonucunun anlamlı olduğu değerlendirilmektedir.

İşgörenlerinin iş yerindeki konumu (çalışan-yönetici) ile iş motivasyonu boyutları arasındaki farklılaşmanın analizi için bağımsız örneklem $t$ testi uygulanmış ve bu sonuca göre iş yerindeki konum ile kontrollü motivasyon alt boyutu arasında istatistiki olarak anlamlı bir farklılık bulunmaktadır. Başka bir ifade ile çalışanların $(X=3,8411)$ kontrollü motivasyon düzeyi yöneticilerden $(X=4,1447)$ daha düşüktür. Bu durumda $\mathrm{H}_{5}$ hipotezi (İş yerindeki konum (yönetici-çalışan) ile iş motivasyonu boyutları arasında anlamlı bir farklılık vardır.) kontrollü motivasyon alt boyutu için kabul edilmiştir. Elde edilen bu sonuçlar Eskildsen vd. (2004) çalışmasında elde edilen sonuçlar ile benzerlik göstermemektedir. Yerli literatürde, konu ile ilgili bir incelemeye rastlanılamamıştır. Örgütsel amaçlar doğrultusunda iş ile ilgili konularda belirli bir kalitenin sağlanması suretiyle işgören performansının belirli seviyede tutulması yöneticilerin sorumlulukları arasında yer almaktadır. Yönetici bu sorumluluğu yerine getirirken hem kendi üslerine hem de astlarına yönelik bazı yükümlülükler altında faaliyetlerini devam ettirmektedir. Bu nedenle, yöneticilerin kontrollü motivasyon düzeyinin çalışanlara göre daha yüksek olduğu sonucunun anlamlı olduğu değerlendirilmektedir.

İşgörenlerin medeni durumu ve toplam çalışma yılı ile iş motivasyonu boyutları arasındaki farklılaşmanın analizi için bağımsız örneklem $t$ testi uygulanmış ve bu sonuca göre medeni durumu ve toplam çalışma yılı ile iş motivasyonları alt boyutları arasında anlamlı bir farklılık bulunamamıştır. Bu durumda $\mathrm{H}_{2}$ hipotezi (Medeni durum ile iş motivasyonu boyutları arasında anlamlı bir farklılık vardır.) ve $\mathrm{H}_{4}$ hipotezi (Çalışma yılı ile iş motivasyonu boyutları arasında anlamlı bir farklılık vardır.) reddedilmiştir. Elde edilen bu sonuçlar Dündar vd. (2007) ve Ertan ve Kaya (2012) ile benzerlik göstermektedir. Ancak Ertürk (2016) çalışmasında elde edilen sonuçlar ile benzerlik göstermemektedir. Medeni durum ile iş motivasyonu boyutları arasındaki farklılaşma esasında bu çalışma kapsamında test edilmemesi gereken bir durum olmakla birlikte elde edilen sonuç beklenildiği gibi çıkmıştır. Araştırmaya katılan bireylerin çevresel faktörleri dikkate alındığında medeni durum ile iş motivasyonu boyutları arasında farklılaşma olmaması çok doğaldır. Ancak özel durumların olması haline değerlendirmeye gerek duyulabilir. Toplam çalışma yılı ile iş motivasyonu boyutları arasındaki farklılaşma ile ilgili literatürde elde ettiğimiz sonuçları destekleyen ve desteklemeyen çalışmalar bulunmakta ve akademik literatürde tam bir mutabakat sağlanmadığı bilinmektedir. Ancak ilerleyen dönemlerdeki çalışmalarla birlikte genel bir kanı oluşturmaya katkı sunması açısından elde edilen sonuç değerlidir.

Yerli literatürde motivasyon konusu; motivasyon türleri, motivasyon araçları ve motivasyon boyutları bağlamında yaygın bir şekilde üzerine çalışılan bir konu olarak yer almaktadır. Literatürdeki çalışmaların sonuçları iş dünyasına, işgörenin motivasyon kaynağı ile gerek işgören gerekse örgüte olan etkilerinin anlaşılması açısından önemli bilgiler sunmaktadır. Bireysel motivasyonun, örgütsel motivasyonun temelini oluşturmasından (Halil ve Aydıntan,2018:134) dolayı bireysel motivasyonun anlaşılması ve bunun örgüt üzerine etkilerinin değerlendirilmesi günümüzdeki rekabetçi şartlara uyumu ve örgütün sürdürülebilirliğinin sağlanabilmesi açısından önem arz etmektedir. Bu nedenle iş dünyasına, akademik çalışmaları okumaları ve değerlendirmeleri önerilir.

Gelecek araştırmacılara, motivasyon konusu farklı meslek grupları özelinde, farklı sektörler (finans, ekonomi, eğitim, inşaat, gıda vb.) özelinde ya da farklı gelir grupları özelinde (asgari ücretliler vb.) çalışma yapmaları önerilir. Ayrıca literatürdeki farklı çalışmaların birlikte değerlendirildiği bir meta analiz çalışması yapılması da literatüre önemli bir katkı sunacağı değerlendirilmektedir. 


\section{A. Göksel - B. Ayan 13/3 (2021) 2174-2187}

\section{KAYNAKÇA}

Ahmed, A. (2019). The Defination of Work Motivation. https://bizfluent.com/facts-6951422-definition-workmotivation.html (Erişim Tarihi: 12 Kasım 2020)

Akkermans, J., Lange, A. H., Heijden, B. I., Kooij, D. T., Jansen, P. G., and Dikkers, J. S. (2016). What about time? Examining chronological and subjective age and their relation to work motivation, Career Development International, 21 (4), 419-439.

Al-Araimi, A. A. (2002). Exploratory study on employees' motivation in the omani private banking sector. Journal of Public Budgeting, Accounting \& Financial Management, 14 (2), 208-220.

Andrews, C. (1-33). Integrating Public Service Motivation and Self-Determination Theory: A Framework. International Journal of Public Sector Management, 29 (3), 2016.

Ankli, R. E., and Ralph Palliam. (2012). Enabling a motivated workforce: exploring the sources of motivation, Development and Learning in Organizations: An International Journal, 26 (2), 7 - 10.

Atkinson, J. W. (1964). Introduction to motivation, Princeton, NJ: Van Nostrand.

Çayırağası, F. (2013). Özel güvenlik sektöründe çalışanların örgütsel bağlllık, iş motivasyonu, iş performans düzeyleri ve bir uygulama, Elektronik Mesleki Gelişim Ve Araştırmalar Dergisi, 1 (1), 34-53.

Çivilidağ, A., ve Şekercioğlu, G. (2017). Çok Boyutlu İş Motivasyonu Ölçeğinin Türk Kültürüne Uyarlanması. Mediterranean Journal of Humanities, 7 (1), 143-156.

Dündar, S., Özutku, H. ve Taşpınar, F. (2017).İçsel ve dıssal motivasyon araçlarının işgörenlerin motivasyonu üzerindeki etkisi: ampirik bir inceleme, Ticaret ve Turizm Egitim Fakültesi Dergisi, 2,105 - 119.

Dharma, Y. (2017). The Effect of Work Motivation on the Employee Performance with Organization Citizenship Behavior as Intervening Variable at Bank Aceh Syariah, Emerald Reach Proceedings Series, $1,7-12$.

Eren, E. (2019). Yönetim ve Organizasyon (Çağdaş ve Küresel Yaklaşımlar). İstanbul: Beta Yayıncllık.

Ertan, H., ve Kaya, İ. (2012). Edremit Körfezi'ndeki Konaklama İşletmeleri Çalışanlarının İş Motivasyon Düzeylerinin Demografik Ve Meslekî Özelliklere Göre İncelenmesi, Sosyal Bilimler Dergisi, 7 (1), 155168.

Ertürk, R. (2016). Öğretmenlerin İş Motivasyonları, Ĕ̆itim Kuram ve Uygulama Araştırmaları Dergisi, 2 (3), 0115.

Eskildsen, J. K., Kristensen, K. and Westlund, A. H., (2004), Work motivation and job satisfaction in the Nordic countries, Employee Relations, 26 (2), 122 - 136.

Franco, L. M., Bennett, S., Kanfer, R., and Stubblebine, P. (2004). Determinants and consequences of health worker motivation in hospitals in Jordan and Georgia. Social Science and Medicine, 58 (2), 343-355.

Gagne, M., and Deci, E. L. (2005). Self-determination theory and work motivation, Journal of Organizational Behavior, 26, 331-362.

Gagne, M., Forest, J., Gilbert, M.-H., Aubé, C., Morin, E., and Malorni, A. (2010). The Motivation at Work Scale: Validation Evidence in Two Languages, Educational and Psychological Measurement, 70 (4), 628-646.

Gagne, M., Forest, J., Vansteenkiste, M., Crevier-Braud, L., Broec, A. V., Aspeli, A. K., . . Johnson, P. A. (2014). The Multidimensional Work Motivation Scale: Validation evidence in seven languages and nine countries, European Journal of Work and Organizational Psychology, 1-19.

Gökkaya, S., ve Türker, N. (2018). İş Motivasyonu İle İş Tatmini Üzerine Otel İşletmelerinde Karşılaştırmalı Bir Araştırma, İktisadi İdari ve Siyasal Araştırmalar Dergisi, 3(5), 12-28.

Gökkaya, Ö., Demir, B., Güngör, Ö. ve Kılıçaslan, İ. (2018). İktisadi işletme çalışanlarının iş motivasyonu düzeylerinin belirlenmesi, Uluslararası Turizm, İşletme, Ekonomi Dergisi, 2 (2),503-508. 
Haggera, M., Hardcastlea, S., Chater, A., Mallet, C., S. P., and Chatzisarantis, N. (2014). Autonomous and controlled motivational regulations for multiple health-related behaviors: between- and withinparticipants analyses, Health Psychology \& Behavioural Medicine, 2 (1), 565-601.

Hong, J.-C., Yang, S.-D., Wang, L.-J., Chiou, E.-F., Su, F.-Y., and Huang, S.-L. (1995). Impact of employee benefits on work motivation and productivity, International Journal of Career Management, 7 (6), 10-14.

Hsu, L. (2013). Work Motivation Job Burn Out, and Employ Mentaspiration in Hospitality and Tourism Students - An Exploration Using the Self-Determination Theory, Journal of Hospitality, Leisure, Sport $\mathcal{E}$ Tourism Education, 13, 180-189.

İyidemirci, H., ve Aydıntan, B. (2018). Motivasyon, Örgütsel Vatandaşlık Davranışı ve İşten Ayrılma Niyeti Arasındaki İlişkinin Belirlenmesine Yönelik Bir Araştırma; Ostim Organize Sanayi Bölgesi Örneği, Gazi İktisat ve İşletme Dergisi, 4(3), 131-144.

Jehn, K. A., Rupert, J. And Nauta, A. (2006) The effects of conflict asymmetry on mediation outcomes: satisfaction, work motivation and absenteeism, International Journal of Conflict Management, 17 (2), 96109.

Kieinginna, P. R., and Kleinginna, A. M. (1981). A Categorized List of Motivation Definitions, with a Suggestion for a Consensual Definition, Motivation and Emotion, 5 (3), 263-291.

Korlén, S., Korlén, S., Essén, A., Essén, A., Lindgren, P., Lindgren, P., . . . von Thiele Schwarz, U. (2017). Managerial strategies to make incentives meaningful and motivating. Journal of Health Organization and Management, 31 (2), 126-141.

Koçel, T. (2014). İşletme Yöneticiliği. İstanbul: Beta Yayıncılık.

Maniksaly, S. (2020). Importance of Motivation in Management. http://www.economicsdiscussion.net/management/importance-of-motivation-in-management/31938 (Erişim Tarihi: 12 Kasım 2020)

McDonald, R., and Spence, C. (2016). Professions and Financial Incentives. In M. Dent, I. L. Bourgeault, J.-L. Denis, and E. Kuhlmann (Eds.), Routledge Companion to the Professions and Professionalism. Oxford: Routledge.

Nohria, N., Groysberg, B., and Lee, L.-E. (2008). Employee Motivation, A Powerful New Model, Harvard Business Review, 86 (7), 78-84.

Parsonsa, E., and Broadbridgeb, A. (2006). Job motivation and satisfaction: Unpacking the key factors for charity shop managers, Journal of Retailing and Consumer Services, 13 (2), 121-131.

Ryan, R. M., and Deci, E. L. (2000). Self-Determination Theory and the Facilitation of Intrinsic Motivation, Social Development, and Well-Being, American Psychological Association, 55 (1), 68-78.

Semerci, A. S. (2005). İş Motivasyonu ve Sonuçları: Türkiye Cumhuriyeti merkez Bankasında Bir Uygulama, Ankara: Uzmanlık Yeterlilik Tezi.

Sökmen, A., Bilsel, M. A., Erbil, C. (2013). Örgütsel Adaletin Çalışan Motivasyonu ve Performansı Üzerindeki Etkisi: Bankacılık Sektöründe Bir Araştırma, Gazi Üniversitesi İktisadi ve İdari Bilimler Fakültesi Dergisi, 15(1), 43 - 62.

Steers, R. M., Mowday, R. T., and Shapiro, D. L. (2004). Introduction to Special Topic Forum The Future of Work Motivaiton Theory, Academy of Management Review, 29 (3), 379-387.

Şantaş, F., Işık, O., ve ÇilHoroz, Y. (2018). Hemşirelerin İş Yaşam Kalitesi, İş Motivasyonu Ve Yaşam Tatmini Algıları Arasındaki İlişkilerin İncelenmesi, Yönetim ve Ekonomi Araştırmaları Dergisi, 16 (1), 64-76.

Toode, K., Routasalo, P., and Suominen, T. (2011). Work motivation of nurses: A literature review. International Journal of Nursing Studies, 48 (2), 246-257.

Vroom, V. H. (1964). Work and motivation. New York: Wiley.

Whiteley, P. (2002). Motivation. Chichester, U.K., Capstone Publishing. 
A. Göksel - B. Ayan 13/3 (2021) 2174-2187

Woodard, G., Cassili, N., and Herr, D. (1998). The relation of management group structure to psychological climate and work motivation in a retail environment, Journal of Fashion Marketing and Management: An International Journal, 2 (4), 304 - 317.

Yang, F. (2011). Work, motivation and personal characteristics: An in-depth study of six organizations in Ningbo, Chinese Management Studies, 5 (3), 272 - 297.

Yazıcıoğlu, F. ve Erdoğan, S. (2014). Spss Uygulamalı Bilimsel Araştırma Yöntemleri. Ankara: Detay Yayıncılık

Yun-Lin, C. Y., and Liu, F.-C. (2012). A cross-level analysis of organizational creativity climate and perceived innovation: The mediating effect of work motivation, European Journal of Innovation Management, 15 (1), 55-76. 